\title{
IMPLEMENTASI MULTIPLE INTELLIGENCES DALAM KEGIATAN EKSTRAKULIKULER DI MADRASAH IBTIDA'IYAH MUHAMMADIYAH KOTA METRO
}

\author{
Kuliyatun \\ Fakultas Agama Islam, Universitas Muhammadiyah Metro Lampung \\ Email : Kuliyatun1971@gmail.com \\ Website : https://jurnal.uin-antasari.ac.id/index.php/ptkpend/index \\ Received: 30 Juni 2020; Accepted: 3 Juli 2020; Published: 3 Juli 2020
}

\begin{abstract}
ABSTRACK
The study tried to focus on the issue of how to apply Multiple Intelligences in the Madrasah Ibtida'iyah Muhammadiyah Metro City Extracurricular activities that began with the input and output processes. As an answer to that problem, then a qualitative method with a phenomenological approach was chosen with the collection of data including question and answer, observation and documentation. The data obtained is then analyzed using the domain analysis method, namely by selecting the data in such a way that a special equation can be categorized with special features. So that it can test its validity by means of triangulation. The results of the study show that in the process of data entry, the application of multiple intelligences in this extracurricular activity has sufficient optimal progress because there are special tools that can be used in measuring multiple intelligences. Furthermore, at the process stage, the application of multiple intelligences in extracurricular activities is also not yet fully optimal because there is not yet a specific follow-up that discusses dual intelligence for extracurricular teachers. Finally, the output stage, the application of multiple intelligences in extracurricular activities is working to the maximum because it has not been able to assess absolutely and complexly.
\end{abstract} Keywords: implementation; multiple intelligences; extracurricular

\begin{abstract}
ABSTRACK
Penelitian mencoba fokus dalam persoalan tentang cara mengaplikasikan Kecerdasan Ganda dalam kegiatan Ekstrakulikuler Madrasah Ibtida'iyah Muhammadiyah Kota Metro yang dimulai dengan proses input dan juga outputnya. Sebagai jawaban dari persoalan itu, maka kemudian dipilihlah metode kualitatif dengan pendekatan fenomenologi dengan pengumpulan datanya adalah tanya jawab, pengamatan dan pendokumentasian. Data yang didapat kemudian dianalisa menggunakan metode analisis domain, yaitu dengan memilih data sedemikian rupa hingga terlihat adanya persamaan khusus yang bisa dikategorikan dengan ciri khusus. Sehingga dapat menguji kevalidannya dengan cara triangulasi. Hasil dari penelitian menampilkan yaitu pada proses pemasukan data, pengaplikasian Kecerdasan ganda di dalam kegiatan Ekstrakulikuler ini cukup memiliki progres yang optimal karena ada alat khusus yang dapat digunakan dalam mengukur Kecerdasan ganda. Selanjutnya, di tahap proses, penerapan Kecerdasan ganda dalam kegiatan Ekstrakulikuler juga belum sepenuhnya optimal karena belum ada sebuah follow up khusus yang membahas mengenai Kecerdasan ganda untuk para guru Ekstrakulikuler. Terakhir, tahap keluaran, penerapan Kecerdasan ganda dalam kegiatan Ekstrakulikuler sedang mengupayakan maksimal karena belum mampu menilai secara absolut dan kompleks.
\end{abstract}

Kata Kunci: implementasi; kecerdasan majemuk; ekstrakulikuler 


\section{PENDAHULUAN}

Saat ini fenomena pendidikan di indonesia masih sangat terdominasi oleh penggunaan test Intelligences Quotient atau biasa di sebut dengan IQ. intelligences quotient saat ini di pergunakan untuk melakukan pengukuran kecerdasan seorang anak. Saat ini seorang guru sebagian besar berfikir tentang mata pelajaran yang bisa mencerminkan tentang bentuk kecerdasan yait: matematika, bahasa, ilmu seputar alam serta ilmu seputar sosial. Pentingnya pendidikan di dalam pembelajaran dengan selalu memerlukan betapa pentingnya aspek-aspek pendidikan akan lebih berkontribusi pada pengembangan intelligensinya. Persoalan tersebut di dasarkan pada aspek kognitif, hingganya fenomena tersebut mempersempit laju yang hanya akan memeilii sebuah kecerdasa kognitif saja.

Proses belajar sebenenarnya bukan hanya mengenai ilmu pengetahuan saja namun fakta tersebut disosialisasikan menggunakan strategi pada kelas tertentui saja. Namun fakta di sekolah konfensional mememiliki sebuah kecenderungan akan memisahkan peserta didik dari dinamika persoalan masyarakat nyata. Lamanya seroang peserta didik melalui proses pendidikan di sekolah maka akan menjauhkan dirinya pada persoalan masyarakat nyata. Sekolah hanya terpusat pada bahan ajarnya saja. Sehingganya siswa-sioswi minim kepeduliannya dengan sekitar. Sistem ajar konvensional inilah yang melahirkan sistem pendidikan yang kaku dan tidak fleksibel sesuai minatnya.

$$
\text { Pola pendidikan yang }
$$

menggunakan sistim pendidikan lama atau tradisional akan melahirkan system pendidikan dengan menuntut pada sikap yang patuh, menerima dan taat. Trend Global untuk pendidikan abad 21 dengan metode belajar peserta didiknya. UNESCO mempunyai visi yang sejalur dengan ideologi Indonesia, sebagimana di kutip dari Mulyasa yaitu yang menempatkan posisi pendidikan dengan empat pilar, (belajar agar tahu), belajar hidup bersamasama serta belajar untuk "be your self". Yang Kedua, hingga akhir hayat mampu mengembangkan pola kecerdasan anak.

Fenomena dengan adanya Garner, dia telah menolak pendapat dalam jiwa setiap orang adalah satu kesatuan dalam seseorang yang hanya memiliki satu kecerdasan saja. Seseorang memiliki sebuah level pengusaan terhadap sesuatu. Seseorang yang hidup di masyarakat di bekali dengan berbagai macam kecerdasan. Intelgensi atau pengetahuan berpadu dalam sosok diri penuh ilmu. Pendapat Gardner membuat anggapan kecerdasan seorang manusia yang selama ini dimuat. Perkembangan anak mempunyai perbedaaan antara satu dan lainnhya. Beberapa penelitian yang melakukan penelitian tentang otak telah membuahkan hasil jika seorang anak diberi sebuah stimulus dari masa kanak-kanak, kemungkinan besar akan di tekukannya soorang anak yang unggul. Hal tersebut di karenakan anak tersebut telah mempunyai beberapa kemampuan yang tak terbatas dalam dirinya. Fenomena di atas menunjukkan bahwa perlu adanya sebuah program pendidikan yang mana akan memberikan output sehingga mampu merangsang kapasitas belajar seorang anak melalau prorgam pendidikan dan pembelajaran seorang anak sejak dini.

Adanya kemampuan seorang anak hendaknya dioptimalkan sejak dini. Hal tersebut dikarenakan bila potensi seorang anak tidak dapat terealisasikan dan berkembang, kemungkinan. Saat ini keberadaan sekolahh tidak lagi melhairkan semua siswa yang pandai semua mata pelajaran di sekolah. Persoalan ini telah dilakukan oleh para guru yang ada di sekolah. Para guru mengingingan anak siswanya cerdas akan mata pelajaran tertentu sesuai dengan bidang dari guru tersebut. Hal itu seolah mengabaikan bahwa anak didik mendapatkan point baik karena dirinya memakai metode hafalan tidak dari substansinya. (Junriadi, 2018). 
Fenomena yang terjadi saat ini sudah jelas bahwa ketika seorang peserta didik atau siswa sedang melnajutkan ke kelas yang lebih tinggi hal tersebut akan berimbas pada terfokusnya kegiatan pada dua kecerdasan yaitu linguistik dan logismatematis. Ketika seorang siswa akan di hadapkan dengan ujian nasional yang selalu terdiri dari dua bagian verbal da matematika, hal tersebut berdampak postif pada seorang siswa yang kuat dan cerdas dalam bidang tersebut, tetapi bagaimana dengan anak yang punya hobi lebih ke seniman misalnya menggambar, mereka yang punya hobi seniman lebih cenderung tidak suka berhitung. Secara akademis, fenomena tersebut seolah terjadi tolak belakang. Modalitas berlebih dapat melahirkan metode belajar dan menambah kesuskesan. Di negara ini, ber-orientasi pada dukunganan yang lebih megacu untuk anak didik yang mengalami permasalahan dalam proses kegiatan belajarnya.

Guru bimbingan dan konseling di negara indonesia lebih terfokus pada siswa yang bermasalah, tapi mengabaikan siswa yang tak memiliki problem. Fenomena di atas sangat berpotensi pada kurangnya perhatian anak-anak dengan metode bimbingan dan konseling. Fenomena. Akhirnya jatah konsultasi jarang sekali dikunjungi siswa karena khawatir dianggap anak nakal. Jadi posisi guru BK saat ini hanya bersifat klinis saja. Karakteristik guru para peserta didik saat ini yang perlu di pahami dengan bagus oleh guru (BK) dan guru mata pelajaran lain akan berkatian dengan keterampilan, bakat dan kepandaiian seseorang. Oleh sebap itu seorang guru yang tidak bagitu paham dengan kecerdasan peserta didiknya dengan baik, maka akan merasakan hambatan dalam memberikan pelayanan dan fasilitas dalam proses merangsang perkembangan kemampuan para murid hingganya akan mempersempit peserta didik dalam proses mengambangkan bakat ataupun kemampua yang akan dimiliki murid
Selanjutnya agar sorang guru mampu melihat potensi IQ yang dipunyai seorang murid hendaknya seorang kecerdasankecerdasan lain dari peserta didik atau kecerdasan berganda.(Suarca, Soetjiningsih, \& Ardjana, 2016: 6)

- Kecerdasan merupakan kemampuan dalam mencari solusi problematika atau menghasilkan suatu kebutuhan di dalam latar budaya khusus. Orang akan disebut pandai jika ia mampu mencari solusi hiodupnya dan dapat menemukan sesuatu berharga dan buat orang lain. Howard Gardner mensosialisasikan hasil penelitian yang berhubungan dengan pendapat kecerdasan majemuk dengan argumennya selama ini berbicara tentang pikiran seseorang (Hanafi, 2016: 10).

Kita dapati penelitiannya tak memperlihatkan bahwa aktivitas murid yang menggunakan banyak pribadi, melainkan semua kecerdasan yang dipunyai. Semua kecerdasan itu berkumpul menjadi satu. Susunan kepadanannya memiliki jenis tiap muridnya. Tteapi, kecerdasan itu bisa diupgrade. Kecerdasan yang menonjol biasanya mengelola kecerdasan yang lain dalam menyelesaikan masalah. Berikut adalah kecerdasan nya : Kecerdasan komunikasi visual, kecerdasan gesture, kecerdasan musikal, kecerdasan alami, kecerdasan religius dan kecerdasan beradaptasi. Beberapa murid memang memiliki kecerdasan itu, tetapi baisanya tidak bisa sefrekuensi, semakin terlihat maka semain baik.

Hakikatnya setiap siswa lahir dengan cerdas membawa bakat dan potensi perorangan yang bisa membuat jadi pintar. Tidak bagus jika sekolah hanya berfokus pada satu sisi saja. (Haderani, 2018). Pendapat yang selalu mencari kelebihan muridnya. Tidak ada anak yang tidak pintar, pasti tiap anak punya kelebihan. Kalau yang menonjol itu bisa diketahui dari pertama, pasti kelebihan itu adalah kemampuan kecerdasan murid. Karenanya sekolah menerima saja jenis tiap anak Tugas Biar nanti sekolah yang menelitri 
dengan metode riset kecerdasan majemuk. Pembagian dan pengeleompokkan yang pandai dan tidak berefek dengan pikiran mereka terutama anak yang tidak pandai. Kepandaian majemuk adalah teori yang ditemukan Howard Gardner.

Teori kecerdasan ganda merupakan jenis pengembangan penting dan menjanjikan dalam pendidikan dewasa ini. Pada dasarnya kecerdasan tidak hanya diukur dari kecerdasan dalam menjawab pembelajaran semata, namun keceradasan manusia juga harus bernilai skill untuk menyelesaikan masalah, kemampuan menemukan persoalan-persoalan baru, kemampuan untuk menciptakan sesuatu. Multiple intelligences lebih dalam menjelaskan ada delapan macam kecerdasan manusia meliputi kecerdasan visual, musikal, perhitungan, gesture intrapersonal interpersonal, dan naturalis. Terserapnya kecerdasan dalam dunia pendidikan, kurikulum apapun yang digunakan oleh berwenang, kecerdasan ganda akan tetap dapat beriringan menjadi wadah pendidikan.

Karena KM (Kecerdasan Majemuk) bukanlah sebuah kurikulum, cara menggunakannya di ruang kelas dan sekolah sama tidak terbatasnya dengan kreativitas dan energi para pendidik yang bekerja sama. Para pendidik yang bekerja sebagai mitra adalah kuncinya. Peluang Karena KM (Kecerdasan Majemuk) untuk tumbuh subur di sekolah akan meningkat selama para guru bekerja sama dan saling belajar dari yang lain. Dapat dikatakan bahwa seluruh sekolah menjadikan Karena KM (Kecerdasan Majemuk) sebagai fokus mereka. Apakah sekolah lama kemudian menjadikan KM (multiple intelligences) sebagai fokus atau sekolah baru yang sejak awal membingkaikan programnya di sekitar Karena KM (Kecerdasan Majemuk), keuntungan menggunakan KM di seluruh sekolah tampak jelas. KM berpotensi membantu anak-anak belajar dan dapat menciptakan lingkungan yang memungkinkan orang dewasa belajar juga.
Saat sekolah berbasis Karena KM (Kecerdasan Majemuk), tiap agendanya akan berubah. Metode pendekatannya pun berbeda-beda, kecuali beberapa perubahan saja yang bisa membuat para murid menjadi melakukan penyesuaian terhadap cara belajar, sebagai contoh adalah cara menghitung dan menulsikan sesuatu. Hal ini membuat metode belajar harusnya cukup memiliki alternatif yang berbeda beda sehingga orang tua memiliki peran besar dalam pengembangan anak anaknya.

Melalui kegiatan ekstrakulikuler yang bermacam-macam, murid dapat mengembangkan minat dan juga bakatrnya sebagai sarana mengembangkan kemmapuan sang murid, sehingga nantinya bisa menjadi lebih baik lagi serta berguna bagi nusa dan bangsa, selain itu kegiatan ekstrakulikuler yang ada di sekolah benarbenar efektif untuk meningkatkan skill dan kapasistasnya.

Pengembangan pribadi seorang murid adalah inti dari pengembangan kegiatan ekstrakulikuler. Karena itu, profile pribadi yang matang adalah tujuan awal kegiatan ekstrakulikuler. Salah satu metode pembelajaran yang mulai berkembang di negara kita adalah sekolah yang berteori kecerdasan majemuk tersebut. Yaitu sekolah yang mengedepankan dan prioritas pada potensi dari para siswa. Model Sekolah yang seperti ini berbeda dari sekolah umum yang cuma melihat dari satu sisi formal saja. Tetapi, di sekolah seperti ini, juga mempunyau fokus yang cukup besar untuk mengembangkan beragam potensi peserta didik, bahkan menjadikannya sebagai prioritas utama. Madrasah Ibtida'iyah Muhammadiyah Kota Metro, tempat dilakukannya penelitian, telah memiliki visi tertentu, dimana visi tersebut memiliki sebuah konsep yang mendasar untuk terwujudnya suatu lembaga pendidikan. Berapa konsep dasar tersebut adalah Spiritual paradigm sebagai core of education tujuan dan arti dari kosep ini yaitu memposisikan bahwa setiap kegiatan belajar hendaknya dilakukan dengan 
mengaitkan paradigma spiritual dengan menjadikan Al-Qur'an dan Sunnah sebagai dasar, Holistic learning proses kegiatan belajar mengajar yang ada di Madrasah Ibtida'iyah Muhammadiyah Kota Metro bertujuan untuk menggali dan mengembangkan potensi yang ada dalam diri peserta didik dengan melihat beberapa aspek kemampuan yang dimiliki oleh peserta didik. Aspek tersebut meliputi aspek intelektual, emosional, spiritual dan fisik.

Multiple intelligences berpadangan bahwa dalam diri setiap anak memilik potensi keceradasan yang selanjtnya kecerdasan tersebut bermacam-macam. Demikan adalah yang harus di pahami oleh seorang guru dalam proses mambantu peserta didik untuk mengembangkan potensinya. Oleh karena itu kegiatan belajar mengajar yang dilaksanakan di Madrasah Ibtida'iyah Muhammadiyah Kota Metro selalu terarah pada pengembanganpengembangan dalam diri peserta didik. Adapun pengembangan tersebut adalah linguistic, musical, naturalist, kinesthetic, spatial ,mathematical, logical, bodily, intrapersonal.

Selanjutnya dalah pertisipasi orang tua dan keluarga lainya dalam membentuk karakter dan akhlaq dimana hal tersebut dilakuan oleh orang tua saat peserta didik ada di rumah. Karena, lingkungan tempat tinggal merupakan penentu daripada pembentukan moral, akhlaq dan karakter seorang peserta didik, hingganya pembelajaran hal-hal yang baik saat peserta didik di rumah dipandang sangat perlu (Diananda, 2018: 5).

\section{METODE PENELITIAN}

Jenis penelitian yang digunakan mengacu pada riset kualitatif dengan berbagai macam pendekatan, Sebagai sarana mencari dan memahami suatu fenomena. Agar penelitian ini bisa mengetahui gejala sentral (Sofian, 2014: 7). Untuk mengetahui gejala sentral tersebut dalam kegaitan penelitian ini akan mewawancarai yaitu guru Ekstrakulikuler yang ada di Madrasah Ibtida'iyah Muhammadiyah Kota Metro juga partisipan dengan cara mengusulkan pertanyaan yang umum (Ridlwan, 1970:9). lnformasi yang disampaikan oleh partisipan kemudian dikumpulkan, lnformasi tersebut dan feomenanya maka kemudian biasanya dikumpulkan berbagai macam sampel dengan menuliskan teks yang telah disediakan. Data yang berupa kalimat kalimat itu nantinya dapat dianalisa akan dia analisa. Hasil analisisanya bisa berupa deskripsi atau dalam bentuk tema-tema. Dari data-data itu peneliti membuat pemahaman untuk menangkap arti yang terdalam .(Ramadania, 2019: 19)

Selepas penelitian maka selanjutrnya adalah tahap evaluasi untuk melihat penelitian sebelumnya yang sudah pernah dilakukan. Hasil akhirnya cenderung lebih fleksibel daripada yang telah dituliskan di awal, yang sangat mempengaruhi berbagai aspek karena disosialisaiskan oleh peneliti.

Tempat riset ini diadakan di Madrsah Ibtida'iyah Muhammadiyah Kota Metro yang menerapkan teori kecerdasan majemuk dari Howard Gardner. Kemudian jadwal sampai jenis kegiatan ekskulnya pun nampak berbeda dari kebanyakan sekolah hingga menjadi daya tarik untuk riset (Phillips, 2014:10).

Jika dilihat dari bentuk atau jenisnya maka dapat dibedakan menjadi data Primer dan data skunder. Data data Primer yaitu data berupa kalimat dari pertanyaan dan diperoleh wawancara dengan informan yang sedang dijadikan data riset. Data pertama adalah data berupa teks hasil bertanya dan diperoleh wawancara dengan informan yang sedang dijadikan prototipe riset (Sugiyono \& Republik Indonesia, 2010:112). Kemudian dibagilah ke dalam tiga macam jenis data:

a. Data dapat dari pembicara atau informan,

b. Data dapay dri lokasi dan peristiwa,

c. Data dapat didokumen resmi atau arsip. 


\section{HASIL DAN PEMBAHASAN}

a. Pengertian Intelligences

Dalam pengertian inteligen adalah beragam, lebih dari tiga puluh tahun lalu Howard Gardner mengembangkan pendapat inteligensi yang berlainan pada teori inteligensi karakteristik.(Legowo, 2017: 2)

\section{b. Pengertian Multiple Intelligences}

Di tahun 1983, Howard Gardner mulai memperkenalkan kepada publik sebuah teori yang dinamakan sebagai Multiple Intelegence atau kecerdasan ganda. Teori Howard Gardner ini menyatakan bahwa kecerdasan atau Intelligences seorang murid dapat melakukan sebuah kemampuan untuk merumuskan batasan dengan melihatnya dari perspektif yang lain atau disebut dengan redefinisi. Sebelum adanya teori kecerdasan ganda atau multiple intelegences, lebih lanjut, teori tentang kecerdasan lebih mengarah pada persoalan yang menyempitkan makna dari kecerdasan itu sendiri, asumsi yang muncul saat ini adalah kecerdasan seseorang lebih banyak ditentukan kemampuan dalam persoalan apakah ia mampu ketika di beri soal-soal yang berkaitan dengan IQ.

Kemudian segala sesuatu yang berkaitan dengan tes IQ dan dapat di selesaikan dengan sempurna, maka itu semua di jadikan sebagai setandar kecerdasan seseorang, namun dalam persolan ini Gardner berhasil mengoptimalkan kebanyakan teori dan test IQ sejak tahun 1905 yang banyak diterapkan oleh pakar konsultan dunia. (Saputra, 2016: 5).

\section{c. Sistem Pendidikan}

Madrasah Ibtida'iyah

Muhammadiyah kota Metro telah mempunyai konsep yang terdiri dari :

Pertama Holistic learning yaitu model evaluasinya bersifat intergral, yaitu meliputi knowledge, life skil dan core of education. Sebagai inti dari pembelajaran, artinya setiap kegiatan belajar yang dilakukan selalu identik dengan pola pikir religius. Fenomena sistem pendididikan yang menggunakan konsep dasar seperti di atas, semua mata pelajaran yang ada di di Madrasah Ibtida'iyah Muhammadiyah kota Metro diajarkan dengan pendekatan tematik. Konsep ini akan membentuk siswa-siswi Madarsah Ibtida'iyah Muhammadiyah Kota Metro yang memiliki beberapa keahlian.

\section{PENUTUP}

Setiap anak dikatakan memiliki kombinasi kecerdasan yang berbeda-beda. Setiap anak akan mempunyai kecerdsan yang menonjol pada bidang tertentu yang ia miliki. Maka jka fenomenanya demikian sudah barang tentu dalam rangka mengupayakan seorang siswa dengan kempuannya yang beragam. perlu adanya fasilitas kegiatan yang mendukung. Sekolah dengan mata pelajarannya, tidak cukup untuk mewakili ragamnya kecerdasan. dihadirkannya kegiatan ekstrakurikuler merupakan salah satu upaya mengembangkan potensi kecerdasan yang beragam itu. Jika kecerdasan itu beragam dan bukan hanya sebatas di mata pelajaran saja, maka tindakan yang seharusnya dilakukan oleh sekolah adalah berusaha melaksanakan kegiatan ekstrakurikuler secara serius juga sama halnya dengan mata pelajaran, agar setiap anak bisa berkembang sesuai dengan potensi yang dimilikinya.

Kegiatan Ekstrakurikuler harus lebih diperhatian dan tidak boleh dianggap 
remeh, karena kegiatan ekstrakurikuler merupakan alah satu upaya bentuk pengembangan kecerdasan yang beragam yang dimiliki oleh setiap murid. Ekstrakurikuler bukan hanya sebagai kegiatan pendukung atau pelengkap saja namun menjadi bagian terpenting dari sekolah dalam rangka mengembangkan potensi masing-masing peserta didik sebaik mungkin.

\section{DAFTAR PUSTAKA}

Diananda, A. (2018). Urgensi Pendidikan Karakter Dalam Pembentukan Konsep Diri Anak. Journal ISTIGHNA, 1(2), $1-21$. https://doi.org/10.33853/istighna.v1i2. 1

Haderani, H. (2018). Tinjauan Filosofis tentang Fungsi Pendidikan dalam Hidup Manusia. Jurnal Tarbiyah: Jurnal Ilmiah Kependidikan, 7(1). https://doi.org/10.18592/tarbiyah.v7i1. 2103

Hanafi. (2016). Pemilihan Profesi Berdasarkan Kecerdasan Majemuk (Multiple Intelligence). Saintifika Islamica: Jurnal Kajian Keislaman, 3(1), 1-20. Retrieved from http://jurnal.uinbanten.ac.id/index.php/ saintifikaislamica/article/download/89/ 91/

Junriadi, H. (2018). Hubungan Pembinaan Kemampuan Mengajar Guru dan Etos Kerja Guru Sekolah Menengah Pertama (SMP) Negeri Kabupaten Tabalong. Jurnal Tarbiyah: Jurnal Ilmiah Kependidikan, 7(2). https://doi.org/10.18592/tarbiyah.v7i2. 2246

Legowo, E. (2017). Model Pembelajaran Berbasis Penstimulasian Multiple Intelligences Siswa. Jurnal Kajian Bimbingan Dan Konseling, 2(1), 1-8. https://doi.org/10.17977/um001v2i120 $17 \mathrm{p} 001$

Phillips, D. C. (2014). Multiple Intelligences: Howard Gardner. In
Encyclopedia of Educational Theory and Philosophy. https://doi.org/10.4135/978148334622 9.n229

Ramadania, F. (2019). Kearifan Lokal Banjar dalam Kumpulan Cerpen Galuh Pasar Terapung Karya Hatmiati Masy'ud (Kajian Etnografi). Tarbiyah: Jurnal Ilmiah Kependidikan, $\quad 8(1), \quad 29$. https://doi.org/10.18592/tarbiyah.v8i1. 2216

Ridlwan, N. A. (1970). Pendekatan Fenomenologi Dalam Kajian Agama. Komunika: Jurnal Dakwah Dan Komunikasi, 7(2). https://doi.org/10.24090/komunika.v7i 2.385

Saputra, T. A. (2016). Pembelajaran IPS Di Sekolah Dasar Berbasis pembelajaran Tematik. EduHumaniora | Jurnal Pendidikan Dasar Kampus Cibiru, 1(2).

https://doi.org/10.17509/eh.v1i2.2736

Sofian, F. A. (2014). Makna komunikasi keluarga bagi wanita karier. Humaniora, 5(1), 468-482.

Suarca, K., Soetjiningsih, S., \& Ardjana, I. E. (2016). Kecerdasan Majemuk pada Anak. Sari Pediatri, 7(2), 85. https://doi.org/10.14238/sp7.2.2005.85 $-92$

Sugiyono, \& Republik Indonesia. Metode Penelitian Kuantitatif \& kualitatif. , Journal of Experimental Psychology: General § (2010). 